\title{
Iridovirus disease in two ornamental tropical freshwater fishes: African lampeye and dwarf gourami
}

\author{
Chaiwud Sudthongkong, Masato Miyata, Teruo Miyazaki*
}

Faculty of Bioresources, Mie University, 1515 Kamihama, Tsu, Mie 514-8507, Japan

\begin{abstract}
Many species of ornamental freshwater fishes are imported into Japan from all over the world. We found African lampeye Aplocheilichthys normani and dwarf gourami Colisa lalia suffering from an iridovirus infection just after being imported by tropical fish wholesalers from Singapore. African lampeye were cultured on the Indonesian Island of Sumatra and dwarf gourami were cultured in Malaysia before export. Diseased fishes displayed distinct histopathological signs of iridovirus infection: systemic appearance of inclusion body-bearing cells, and necrosis of splenocytes and hematopoietic cells. Electron microscopy revealed viral particles (African lampeye:180 to $200 \mathrm{~nm}$ in edge to edge diameter; dwarf gourami: 140 to $150 \mathrm{~nm}$ in diameter) in an inclusion body within the cytoplasm of inclusion body-bearing cells as well as in the cytoplasm of necrotized cells. Experimental infection with an iridovirus isolate from African lampeye (ALIV) revealed pathogenicity of ALIV to African lampeye and pearl gourami Trichogaster leeri. Polymerase chain reaction (PCR) products from ALIV and an iridovirus isolate from dwarf gourami (DGIV) using iridovirus-specific primers were indistinguishable. The nucleotide sequence of PCR products derived from ALIV (696 base pairs) and DGIV (701 base pairs) had $95.3 \%$ identity. These results indicate that ALIV and DGIV have a single origin.
\end{abstract}

KEY WORDS: Tropical iridovirus · African lampeye · Dwarf gourami · Inclusion body-bearing cells · Polymerase chain reaction assay $\cdot$ DNA sequence

Resale or republication not permitted without written consent of the publisher

\section{INTRODUCTION}

An irido-like virus was found in diseased dwarf gourami Colisa lalia that were imported to Australia from Singapore in 1988 (Anderson et al. 1993). In 1989 a similar iridovirus disease was found in diseased orange chromide cichlid Etroplus maculatus after the fish were imported to Canada from Singapore by a tropical fish wholesaler (Armstrong \& Ferguson 1989). Dwarf gourami is a freshwater fish native to eastern India and Bangladesh. Chromide cichlid is a freshwater fish native to India and Sri Lanka. They are popular ornamental fishes. Many are cultured in Singapore before export. The Singaporean government has been encouraging fish breeders to culture various kinds of tropical fishes and to trade them abroad. Singaporean

*Corresponding author. E-mail: miyazaki@bio.mie-u.ac.jp breeders import popular ornamental fishes from all over the world and culture them not only in Singapore but also in neighboring countries such as Malaysia, Thailand and Indonesia.

In Japan, many species of ornamental freshwater fishes are imported from Singapore as well as from all over the world. We found African lampeye Aplocheilichthys normani and dwarf gourami suffering from an iridovirus infection just after being imported from Singapore by tropical fish wholesalers. African lampeye is a freshwater fish native to Sierra Leone, Nigeria and Cameroon. The African lampeye were transported to Singapore and have been cultured since about 1990 and subsequently have been cultured on Sumatra Island, Indonesia, where most are produced. Diseased fish of African lampeye displayed pathological signs that were the same as those displayed in iridovirus infections of dwarf gourami (Anderson et al. 1993); orange chromide cichlid (Armstrong \& Ferguson 1989); 
brown-spotted groupers Epinephelus tauvina (Chua et al. 1994) and E. malabaricus (Danayadol et al. 1996), farmed in Singapore and Thailand, respectively; sea bass, Lateolabrax sp., captured in the South China Sea (Jung et al. 1997); mandarin fish Siniperca chuatsi, reared in offshore pens in the South China Sea in China (He et al. 2000); red sea bream Chrisophylus major (= Pagrus major, Inouye et al. 1992), yellowtail Seriola quinqueradiata, and striped jack Caranx delicatissimus, etc., farmed in Japan (Miyazaki unpubl.); and striped beakperch Oplegnathus fasciatus, cultured in Korea (Jung \& Oh 2000).

Here we present the results of histopathological and electron microscopic (EM) examinations of the diseased African lampeye and dwarf gourami. We report the results of artificial infections with an isolate from African lampeye to African lampeye and pearl gourami. We also describe a polymerase chain reaction (PCR) assay and DNA sequence analysis of the PCR products for identification of iridovirus isolates from African lampeye (ALIV) and dwarf gourami (DGIV).

\section{MATERIALS AND METHODS}

Histopathological and EM examinations, virus culture in natural outbreaks. Diseased African lampeye and dwarf gourami were found just after being imported to Japan from Singapore by tropical fish wholesalers. The African lampeye had been cultured in freshwater ponds on Sumatra Island, Indonesia, and the dwarf gourami had been cultured using artificial diets in freshwater ponds in Malaysia. These fishes were exported via Singapore. We sampled 20 diseased adult African lampeye at an ornamental fish shop in 1998 and 20 diseased adult dwarf gourami from a Japanese wholesaler in 2000.

All sampled fishes were dissected after external and internal observations. Pieces of the visceral organsheart, spleen, liver, digestive tracts, kidney, brain and gills - as well as the lateral muscle of half of the sampled fishes were fixed in $10 \%$ phosphate-buffered formalin for histological examination. The fixed tissues were prepared according to standard techniques and stained with hematoxylin and eosin, azan and Giemsa. Half of the remaining visceral organs was fixed in $70 \%$ Karnovsky's solution, postfixed in $1 \% \mathrm{OsO}_{4}$ and processed for EM.

Grunt fin (GF) cells, cultured with basal medium containing $5 \%$ fetal bovine serum at $25^{\circ} \mathrm{C}$ in $25 \mathrm{~cm}^{2}$ flasks, were used for virus isolation. For primary viral culture, whole bodies of 3 diseased African lampeye or a piece of the spleen of a diseased dwarf gourami was homogenized in 10 volumes of basal medium in a glass homogenizer. The homogenate was centrifuged at $1000 \times g$ for $10 \mathrm{~min}$, and the supernatant was filtered $(450 \mathrm{~nm})$. Each $0.5 \mathrm{ml}$ filtrate was inoculated onto GF cells in $5 \mathrm{ml}$ of the culture medium. Inoculated cells were incubated until the cytopathic effect was complete. GF cells were also used for viral enumeration using 96-well plates. Whole bodies of the remaining African lampeye and the spleens of the remaining dwarf gourami were stored at $-80^{\circ} \mathrm{C}$ for future examination.

Experimental infections. For infectivity experiments, iridovirus-free African lampeye were obtained from the fish that had been cultured in an ornamental fish shop and had not experienced mortality over a long period. In contrast, it was difficult to obtain iridovirusfree dwarf gourami because of the extent of iridovirus infection among them. Therefore, instead of dwarf gourami, iridovirus-free pearl gourami Trichogaster leeri were obtained from an ornamental fish shop and used for experimental infection.

In the infectivity experiments with ALIV, African lampeye were exposed to ALIV by bath immersion. Five milliliters of supernatant from ALIV-infected GF cell medium was diluted into $100 \mathrm{ml}$ of freshwater to a virus level of $10^{5} \mathrm{TCID}_{50} \mathrm{ml}^{-1}$, and 12 healthy African lampeye were exposed for $2 \mathrm{~h}$ (Group 1). In a second type of exposure, the whole bodies of 3 diseased African lampeye were mixed, homogenized and centrifuged. Five milliliters of filtrate (450 nm filter) from the supernatant was diluted into $100 \mathrm{ml}$ of freshwater to a virus level of $10^{7} \mathrm{TCID}_{50} \mathrm{ml}^{-1}$, and 18 healthy African lampeye were exposed for $2 \mathrm{~h}$ (Group 2). One control group (10 fish) was established and treated in the same way as the experimental groups using uninfected GF cell medium. Both fish and water were moved into aquaria containing $10 \mathrm{l}$ of freshwater, and the fish were observed for $14 \mathrm{~d}$ at $28^{\circ} \mathrm{C}$.

To determine the pathogenicity of ALIV to pearl gourami by artificial infection, an inoculum $(0.1 \mathrm{ml})$ prepared from the homogenate of diseased African lampeye as described above was injected into the abdominal cavities of 20 pearl gourami. Ten control fish were injected with Eagle's minimum essential medium (Nissui). Injected fish were reared with feeding for $30 \mathrm{~d}$ at $25^{\circ} \mathrm{C}$ in aquaria (20 l).

Moribund and dead fish were collected daily and processed for histopathology, EM and PCR test; however, virus levels in diseased fishes were not examined as in the case of natural outbreaks.

PCR amplification. DNA was extracted from ALIV and from DGIV by the Proteinase K lysis method (Sambrook et al. 1989, modified by Miyata et al. 1997). Approximately 10 to $50 \mathrm{mg}$ of spleens excised from naturally iridovirus-infected dwarf gourami or pieces of the body of naturally iridovirus-infected lampeye was homogenized in a $0.5 \mathrm{ml}$ aliquot of the $1 \times$ Proteinase $\mathrm{K}$ lysis buffer (50 mM Tris- $\mathrm{HCl}, 10 \mathrm{mM}$ EDTA, 
$2 \%(\mathrm{w} / \mathrm{v})$ sodium dodecyl sulfate, $10 \mu \mathrm{g} \mathrm{ml} \mathrm{m}^{-1}$ Proteinase $\mathrm{K}$ ) in a glass homogenizer. To avoid contamination, DNA was isolated on different days for each sample. The homogenate was incubated at $55^{\circ} \mathrm{C}$ for $3 \mathrm{~h}$ with gentle agitation. After incubation, the lysate was vigorously mixed with a $0.5 \mathrm{ml}$ aliquot of TE buffer (10 mM Tris-HCl, 1 mM EDTA, pH 8.0)-saturated phenol for $3 \mathrm{~min}$, and the mixture was centrifuged at $15000 \mathrm{rpm}$ (approx. $20000 \times g$; Beckman GS-15R with $\mathrm{F} 2402 \mathrm{H}$ rotor) for $5 \mathrm{~min}$ at $20^{\circ} \mathrm{C}$. The supernatant was transferred into a new tube and mixed with $50 \mu$ l of $3 \mathrm{M}$ sodium acetate and $1.5 \mathrm{ml}$ of $99 \%$ ethanol. After precipitation for $15 \mathrm{~min}$ on ice, the sample was centrifuged at $15000 \mathrm{rpm}$ for $10 \mathrm{~min}$ at $4^{\circ} \mathrm{C}$. The DNA pellet was washed with $2 \mathrm{ml}$ of $75 \%$ ethanol and dissolved in $100 \mu \mathrm{l}$ of TE buffer.

In the present study, 4 previously established iridovirus-specific primer sets for PCR (Table 1) were used. PCR was performed using high fidelity Taq polymerase (LA-Taq, Takara). The reaction mixture contained 0.25 units of Taq polymerase, $2.5 \mu$ of $10 \times$ LA PCR buffer, $2.5 \mu \mathrm{l}$ of $25 \mathrm{mM} \mathrm{MgCl}_{2}, 2 \mu \mathrm{l}$ of $2.5 \mathrm{mM}$ of each deoxynucleotide triphosphate mixture, DNA template (>100 ng), $0.25 \mu \mathrm{l}$ of each primer (100 pmol $\left.\mathrm{\mu l}^{-1}\right)$ and distilled water to a total volume of $25 \mu$ l. The temperature for PCR amplification was controlled with a Gene Amp PCR System 9700 (PE Applied Biosystems). PCR amplification by Taq polymerase involved 30 cycles: $2 \mathrm{~min}$ for denaturation at $94^{\circ} \mathrm{C}, 30 \mathrm{~s}$ at $50^{\circ} \mathrm{C}$ for annealing and $2 \mathrm{~min}$ at $72^{\circ} \mathrm{C}$ for extension. After the thermal cycling, the samples were post-heated at $72^{\circ} \mathrm{C}$ for $5 \mathrm{~min}$. PCR products were separated by electrophoresis on a $1 \%$ agarose gel and visualized by ethidium bromide staining. For a negative control of PCR, genomic DNAs were isolated from the whole body of healthy African lampeye and the spleen of healthy pearl gourami.

ALIV and DGIV were compared with 3 previously identified iridoviruses from sea bass (SBIV) (Jung et al. 1997, Miyata et al. 1997), brown-spotted grouper with sleepy disease (GSDIV) (Danayadol et al. 1996) (= GSIV; Jung et al. 1997) and red sea bream (RSIV). All 5 iridovirus isolates were simultaneously processed in PCR tests using the same primer sets. SBIV, GSDIV and RSIV had been stored at $-80^{\circ} \mathrm{C}$ since the day of collection.

Cloning and sequencing of PCR products from ALIV and DGIV. PCR products that were derived from ALIV and DGIV with the iridovirus-specific primers P3-IRB5 and P4-IRB5 (where they corresponded to the downstream region of the iridoviral ATPase gene) were cloned and sequenced. PCR products of ALIV and DGIV were connected to pGEM-T (Promega) following the supplier's recommendations. The recombinant plasmid was transformed with Escherichia coli
Table 1. Primers used for PCR analysis

\begin{tabular}{|c|c|c|}
\hline & PCR primer & Product \\
\hline P1-IRB6 & 5'-GGCGGTTAGCTCAGGACGGG-3' & \\
\hline P2-IRB6 & 5'-TGTGTTTCATTTATTGTTGTTGCGC-3' & 412 \\
\hline P3-IRB6 & 5'-GTACGGGGCTTGATGATGACGT-3' & \\
\hline P4-IRB6 & 5'-CCTTGTGTCGTGTCTGGCCGAG-3' & $709^{a}$ \\
\hline P1-IRB6 & 5'-AAGGCTGTTGGATTTTGAGAGGTG-3' & \\
\hline P2-IRB6 & 5'-GTAAACTTCCTTGATGTGTGCGATG-3' & $467^{\mathrm{b}}$ \\
\hline P3-IRB6 & 5'-CCATCGTCAAGCAGTGTAGGCGG-3' & \\
\hline P4-IRB6 & 5'-CAGGAAAGTAGTGAGGGCAGAAGC-3' & 795 \\
\hline${ }^{\text {a }}$ Codes ir & dovirus ATPase gene & \\
\hline${ }^{\mathrm{b}}$ codes ir & dovirus DNA polymerase gene & \\
\hline
\end{tabular}

strain XL1-Blue $\mathrm{MRF}^{\prime}$ (Stratagene) as described by Sambrook et al. (1989), and recombinant clones were extracted using the alkali-sodium dodecyl sulfate method. Nucleotide sequences were determined with the Thermosequenase fluorescent-labeled primer cycle sequencing kit (Amersham Pharmacia Biotech) with DNA sequencer DNA 4000L (Li-Cor).

\section{RESULTS}

\section{Infection experiments}

The results of infection experiments are shown in Fig. 1. African lampeye that were infected by placing them in a suspension of ALIV displayed high mortality, indicating that ALIV was stable in freshwater and highly pathogenic. ALIV was also highly pathogenic to pearl gourami. On the other hand, there was no mortality in control groups.

\section{Clinical observations, histopathology, EM, and virus isolation and culture}

Diseased African lampeye, dwarf gourami and pearl gourami in both natural outbreaks and artificial infections variably displayed either a pale coloration or a dark coloration of the body (Fig. 2A-C) and sometimes ascites. All of the fish showed splenomegaly and pale gills. Histopathological signs were the same in natural outbreaks and artificial infections: systemic formation of many inclusion body-bearing cells (IBCs), and necrosis of splenic cells and hematopoietic cells. The early stage of IBCs were hypertrophied blast-like cells that possessed a basophilic cytoplasm and a centrally located, enlarged nucleus containing prominent nucleoli (Fig. 3C,D) These features of the early stage of IBCs resembled those of macrophages. The mature 


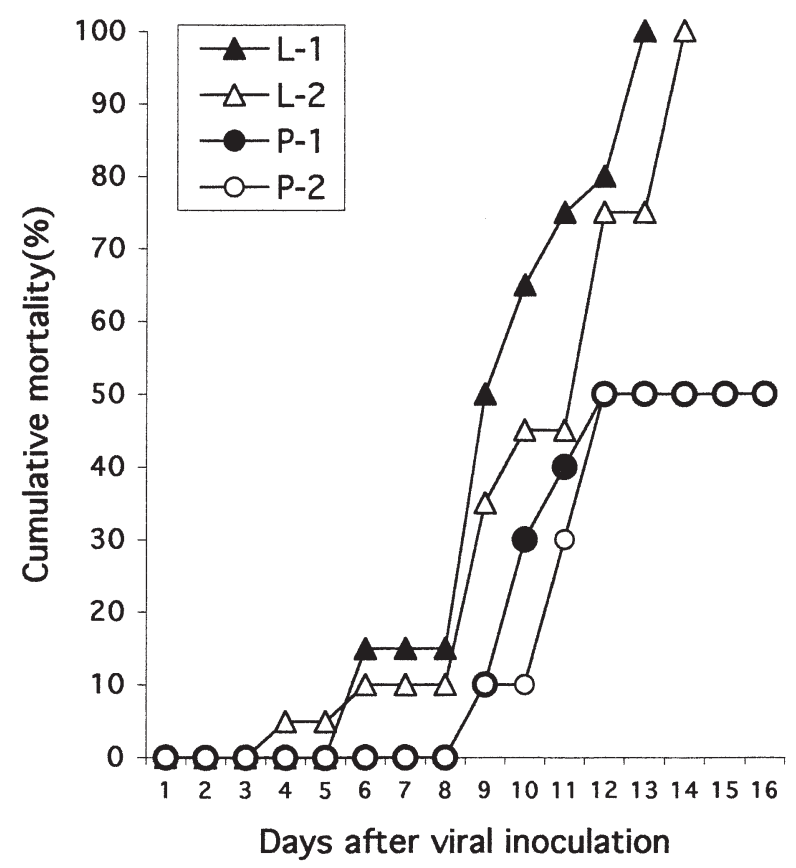

Fig. 1. Cumulative mortality of African lampeye and pearl gourami after artificial infections with iridovirus isolates. L-1: African lampeye that were exposed to iridovirus isolate from African lampeye (ALIV) by placing them in a suspension of the cultured virus. L-2: African lampeye that were exposed to ALIV by placing them in a suspension containing filtrate $(450 \mathrm{~nm})$ of homogenized fish body of diseased African lampeye. P-1 and -2: pearl gouramies injected with filtrate $(450 \mathrm{~nm})$

of homogenized fish body of diseased African lampeye

IBCs were enlarged and usually had an entirely basophilic cytoplasm and either a centrally or marginally located nucleus (Fig. 3A,C,D). The marginated nuclei were usually compressed or pyknotic. The ballooning degenerated IBCs had an expanded inclusion body with a granular appearance within a marginally compressed, narrow cytoplasm that contained a highly pyknotic or fragmented nucleus (Fig. 3A,C). The highly ballooning cells had an inclusion body with a clear appearance within the surrounding thinned cytoplasm. Iridovirus-infected lesions were most markedly induced in the spleen. Many IBCs appeared in pulpic
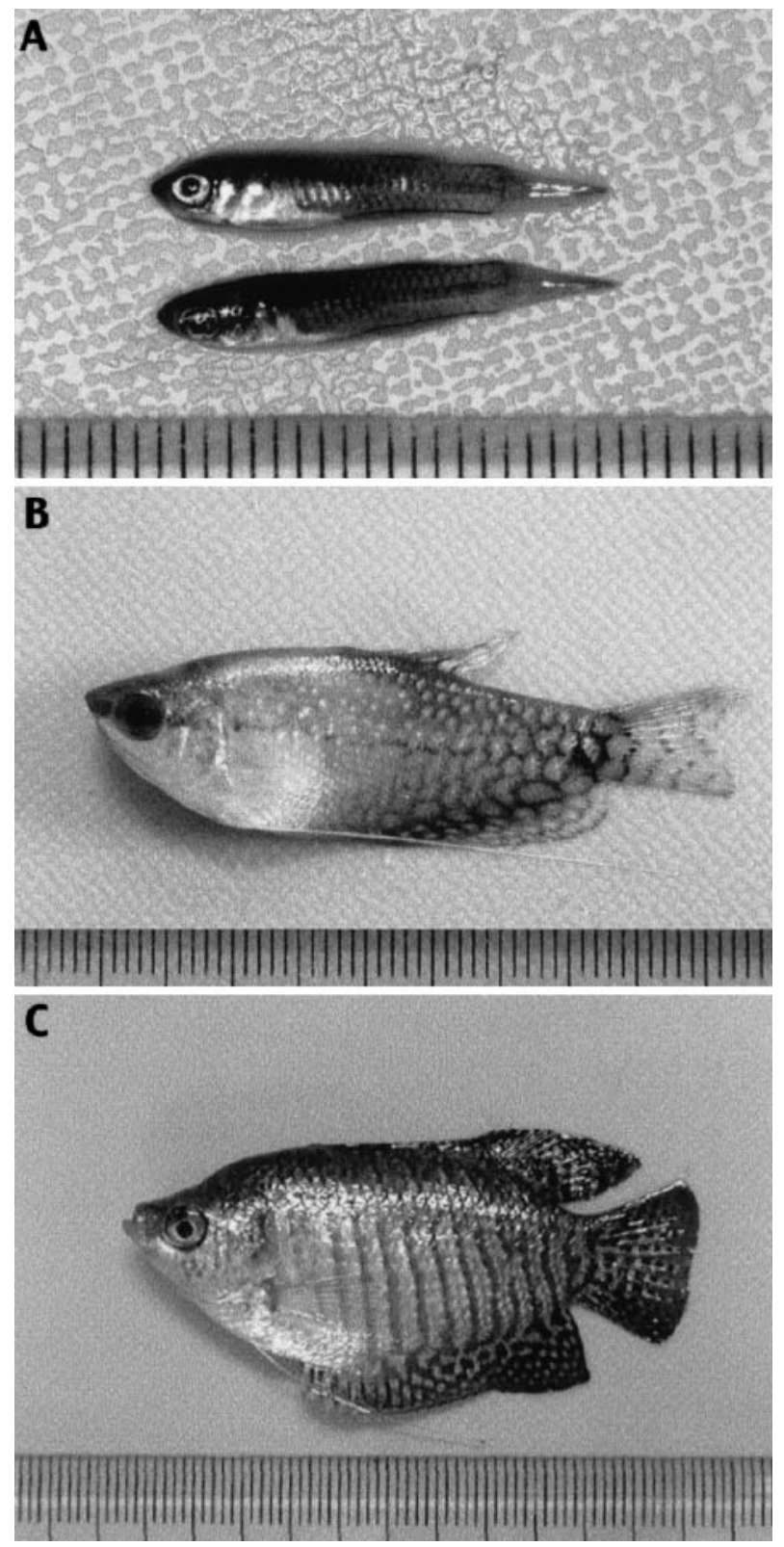

Fig. 2. Tropical iridovirus-infected fishes. (A) African lampeye showing the pale body coloration from a natural outbreak. (B) Dwarf gourami displaying the pale body coloration from a natural outbreak. (C) Pearl gourami with the dark body color from an artificial infection

Fig. 3. Tropical iridovirus. (A) The spleen of an African lampeye from a natural outbreak displays many inclusion body-bearing cells (IBCs) and necrotic cells in the pulp. Hematoxylin and eosin (H\&E) stain, scale bar $=20 \mu \mathrm{m}$. (B) Electron micrograph of a necrotized splenocyte shows many virions within a membranous structure among fragmented or degenerated organella. Virions have a hexagonal conformation and sizes ranging from 180 to $200 \mathrm{~nm}$. Scale bar $=1000 \mathrm{~nm}$. (C) The intestine of an African lampeye from an artificial infection displays many IBCs in the tunica propria and submucosa. In the early stage of IBCs hypertrophied cells possess an enlarged nucleus and contain prominent nucleoli. H\&E stain, scale bar $=20 \mu \mathrm{m}$. (D) The spleen of a dwarf gourami from a natural outbreak displays many of early stage IBCs, mature IBCs and necrotic cells in the pulps. H\&E stain, scale bar $=$ $20 \mu \mathrm{m}$. Small arrows point to mature IBCs and large arrows point to ballooning degenerated IBCs 


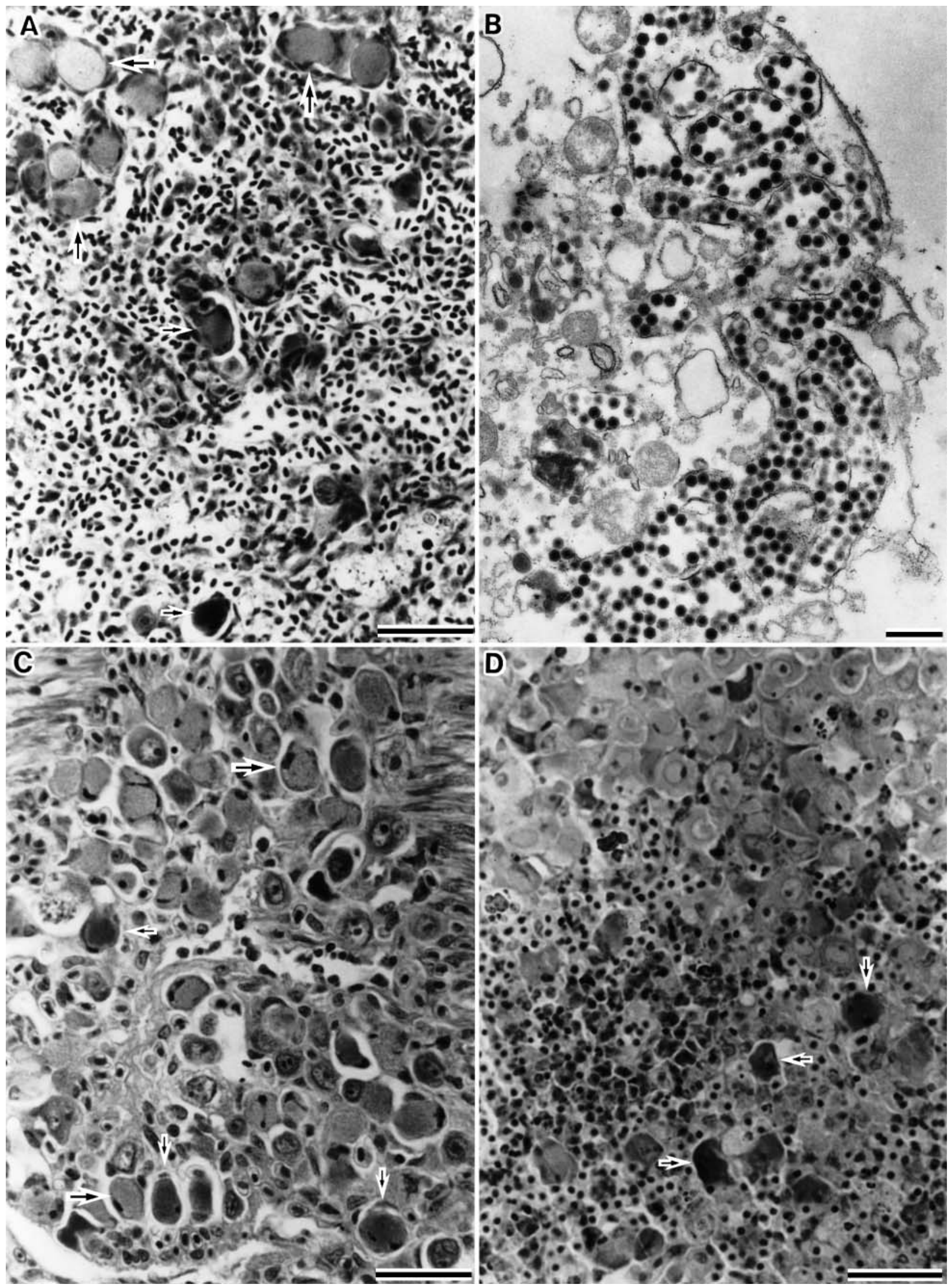





Fig. 4. Tropical iridovirus. (A) The kidney of a dwarf gourami from a natural outbreak displays many mature IBCs in the hematopoietic tissue. (B) The intestine of a pearl gourami from an artificial infection displays many mature IBCs in the tunica propria. H\&E stain, scale bars $=20 \mu \mathrm{m}$. Arrows point to mature IBCs

tissues, sheathed tissues and splenic sinuses (Fig. 3A,D). Necrotic splenocytes also occurred accompanied by hemorrhage in pulpic tissues. Many IBCs appeared in the tunica propria and submucosa in the stomach and intestine (Figs. 3C \& 4B). In the kidney, many IBCs appeared inside the glomerular capillaries and the hematopoietic tissues, in which necrotic hematopoietic cells also occurred (Fig. 4A). In the liver, IBCs appeared within sinusoids and in the connective tissue surrounding the intrahepatic pancreas as well as in the omentum. In some fish, the liver contained necrotic foci of parenchymal cells. In the heart, a small number of IBCs appeared in the endocardium and epicardium. A few IBCs were sometimes present in the meninges of the brain. However, most gills contained no IBC.

EM of mature IBCs revealed the formation of a large inclusion body that consisted of the matrix of fine granules containing many virions, rough endoplasmic reticula (rER), smooth endoplasmic reticula (sER) and mitochondria, and abundant ribosomes within a marginally compressed cytoplasm (Fig. 5A). The inclusion bodies of African lampeye also contained many rod-shaped

Fig. 5. Tropical iridovirus. Electron micrographs of IBCs of African lampeyes. (A) A mature IBC shows the inclusion body that consists of the granular matrix containing many virions, rough endoplasmic reticulum (rER) and mitochondria, and abundant ribosomes and rod-shaped structures within the marginally compressed cytoplasm of the host cell. The cytoplasm contains many rERs, ribosomes and mitochondria, and some lysosomes. Scale bar $=1200 \mathrm{~nm}$. (B) A ballooning degenerated IBC displays an expanded inclusion body containing many virions, degenerated mitochondria, fragmented organelles and red-shaped structures that are often clumped (arrows). The surrounding cytoplasm of the host cell is thinned and partially destroyed. Scale bar $=$ $1400 \mathrm{~nm}$. (C) A detail of virions in an inclusion body. Virions show crystal array and have a hexagonal conformation and a 170 to $200 \mathrm{~nm}$ edge to edge diameter. Scale bar $=400 \mathrm{~nm}$. c: cytoplasm of host cell; i: inclusion body; m: membranous border; n: nucleus of host cell 






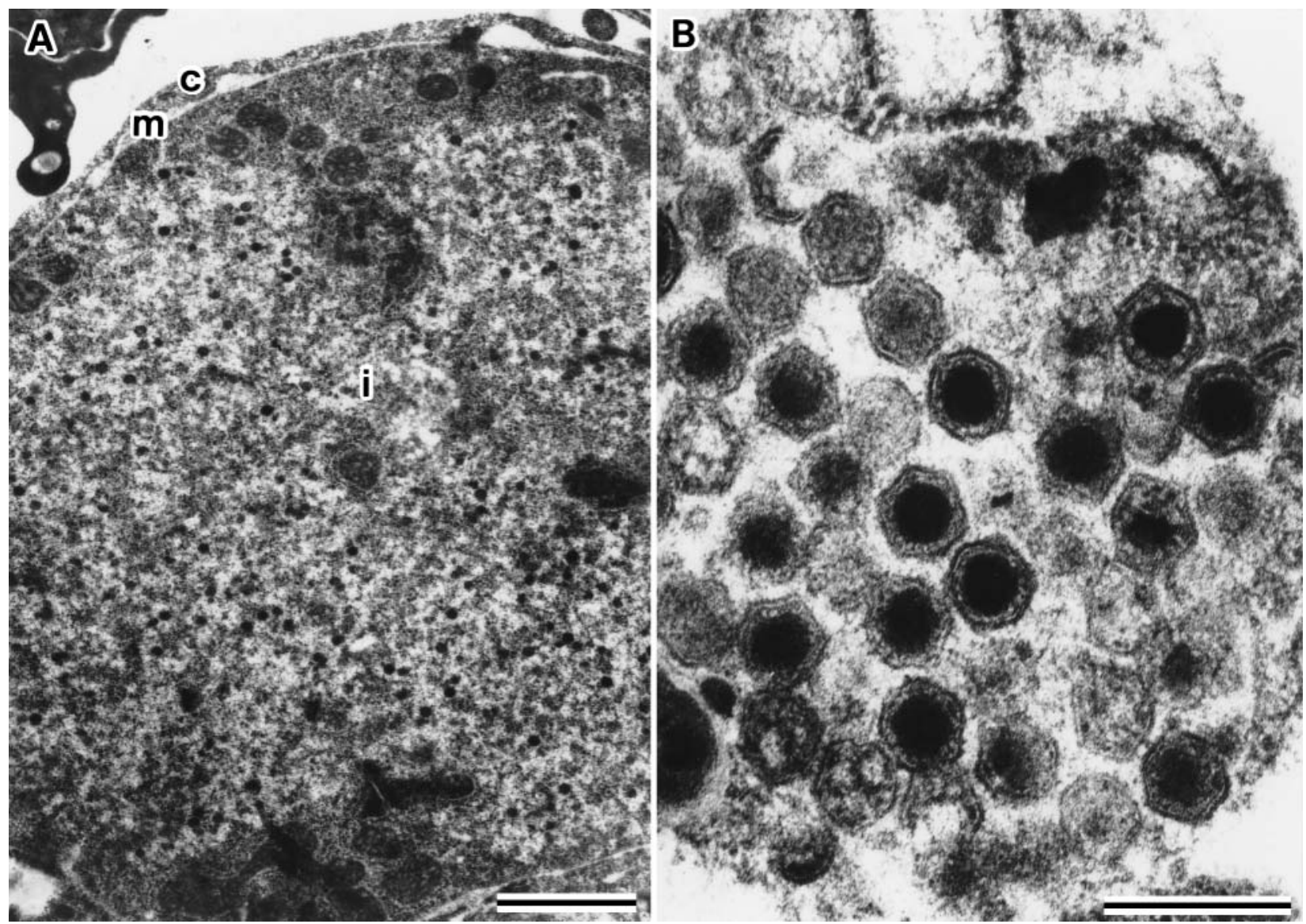

Fig. 6. Tropical iridovirus. Electron micrographs of IBCs of dwarf gourami. (A) A ballooning degenerated IBC displays an expanded inclusion body containing many virions, degenerated mitochondria and fragmented organelles. The surrounding cytoplasm of host cell is thinned. Scale bar $=2000 \mathrm{~nm}$. (B) A detail of virions. Virions have a hexagonal conformation and a 140 to $150 \mathrm{~nm}$ edge to edge diameter

structures that sometimes formed clumps. The marginated cytoplasm had many mitochondria, rER and ribosomes, and some lysosomes. The inclusion bodies were sometimes delimited with a membranous structure from the surrounding cytoplasm of host cells. In some cases, the border was indistinguishable between the inclusion body and the host cell cytoplasm. The early stage of IBCs that had already formed a small inclusion body were the same as those that were observed in RSIV (Jung et al. 1997). The feature of inclusion bodies of the early stage of IBCs resembled that of mature IBCs except for few virions or a small number of virions being assembled. On the other hand, EM of ballooning degenerated IBCs revealed an electron-lucent inclusion body that contained a decreased number of virions, fragmented organelles and degenerated mitochondria (Figs. 5B \& 6A). The surrounding cytoplasm of host cells was compressed, and contained fragmented organelles and degenerated mitochondria. Virions of DGIV and ALIV showed a hexagonal outline and contained an electron-dense core. The diameter of ALIV was 170 to $200 \mathrm{~nm}$ from edge to edge (Fig. 5C) and that of DGIV was 140 to $150 \mathrm{~nm}$ from edge to edge (Fig. 6B). EM of necrotized splenocytes revealed marked accumulation of iridovirus virions among degenerated and fragmented organelles within the cytoplasm (Fig. 3B).

\section{PCR analysis and DNA sequences of ALIV and DGIV}

PCR amplification using 4 previously developed iridovirus-specific primer sets (P1-IRB5 and P2-IRB5, P3-IRB-5 and P4-IRB5, P1-IRB6 and P2-IRB6, and P3IRB6 and P4-IRB6) produced products from ALIV and DGIV isolated from freshwater fishes as well as from the known iridoviruses SBIV, RSIV and GSDIV from marine fishes. The PCR products from these 5 iridovirus isolates all had the same size. The PCR products coincided with the particular fragment sizes: 416 base 

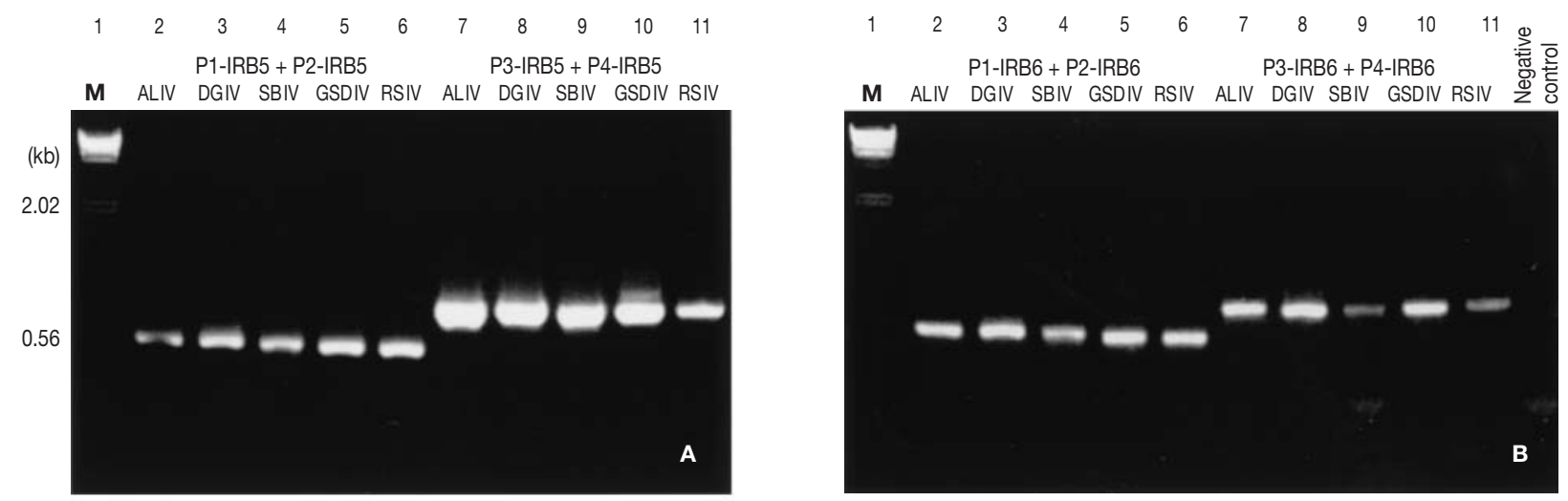

Fig. 7. Tropical iridovirus. PCR diagnostic assay for ALIV and iridovirus isolates from dwarf gourami (DGIV), sea bass (SBIV), brown-spotted grouper with sleepy disease (GSDIV) and red sea bream (RSIV). In (A) HindIII-digested $\lambda$ DNA serves as a size maker ( $\mathrm{M}_{i}$ lane 1). PCR products derived from ALIV, DGIV, SBIV, GSDIV and RSIV (from left to right) with P1-IRB5 and P2-IRB5 of the iridovirus-specific primers are in lanes 2 to 6, and primers P3-IRB5 and P4-IRB5 are in lanes 7 to 11). In (B) HindIII-digested $\lambda$ DNA serves as a size maker (M; lane 1). PCR products from ALIV, DGIV, SBIV, GSDIV and RSIV (from left to right) with primers P1-IRB6 and P2-IRB6 are in lanes 2 to 6, and primers P3-IRB6 and P4-IRB6 in lanes 7 to 11. These PCR products from ALIV, DGIV, SBIV, GSDIV and RSIV show genetic homogeneity

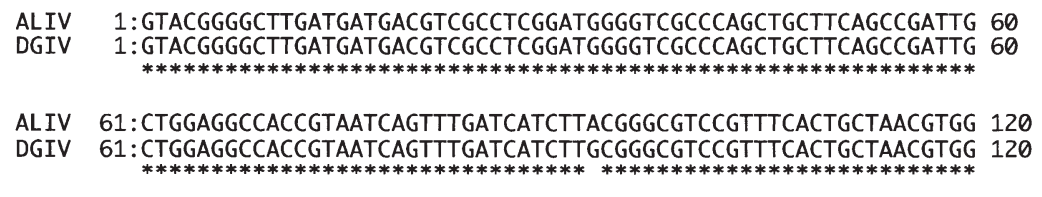

ALIV 121:TCGTGTAGCACATGGCCAGACTTGAAGAGCTTCACGCCGTCCGGCGTGACGCCTTTGCGC 180 DGIV 121:TCGTGTAGCACATGGCCAGACTTGAAGAGCTCCACGCCGTCCGGCGTGACGCCTTTGCGC 180 $* * * * * * * * * * * * * * * * * * * * * * * * * * * * * * * * * * * * * * * * * * * * * * * * * * * * * * * * * * * * * *$

ALIV 181:TCTGGCTGTTGTACCTGACGCTTTGAGCGTTCATAGTACACCACCATGAGCGCAAGGACC 240 DGIV 181:TCTGGCTGTTGTACCTGACGCTTTGAGCGTTCATAGTACACCACCATGAGCGCAAGGACC 240 $* * * * * * * * * * * * * * * * * * * * * * * * * * * * * * * * * * * * * * * * * * * * * * * * * * * * * * * * * * * * *)$

ALIV 241: ATGGAAATGGAACTAGACATAAAAATAGGATCCACCATGGTTATATTTAGGAAAAAAAGT 300 DGIV 241: ATGGCAATGGCACTAGACATGACAATAGGATCCACTATGGTTTTCTTTAGGCGAAAAAGT 300 $* * * * * * * * * * * * * * * * * * * * * * * * * * * * * * * * * * * * * * * * * * * *) * * * * * * *$

ALIV 301:ATTTATTGTTCCGGGCCATGAGAAACCATATAAAATAAAAAACCCATC-AATTAGGCGTG 359 DGIV 301: CTTTATTGTTCCGGGCCATGAGAAACCATGTCAAATTATGATCCCCTCTAATTAGGCGTG 360 $* * * * * * * * * * * * * * * * * * * * * * * * * * * * * * * * * * * * * * * * * * * * * * * * * * *$

ALIV 360: CAACGTTGTGCCCATTCCAGCGCTCCTGGAGCGGTGCGACGCTCCCCCGTCTAAACGCCT 419 DGIV 361: CAACGTTGTGGCCATTCCAGCGCTCCTGGAGCGGTGCGACGCTGTCCAGTATAAACGCCT 420 *******************************************)*************

ALIV 420:TCTGCG--CCGCCCAGCTCGTCGTAGTGCAGTGCCAGCAA-GCCGGCTGTGCTAGGCTTG 476 DGIV 421:TCTGCGCACCGCCCAGCTCGTCGTAGTGCAGTGCCAGCAACGCCGGCTGTGCTAGGCTTG 480 $* * * * * * \quad * * * * * * * * * * * * * * * * * * * * * * * * * * * * * * * * * * * * * * * * * * * * * * * * * * * * *$

ALIV 477: CGTTCAGGGCGAAGCATGCCTGTGCGAAGCCGTCGTACTGGGACATGACTGTGGCCAGCA 536 DGIV 481: CGTTCAGGGCGAAGCATGCCTGTGCAAAGCCGTCGTACTGGGACATGACTGTGGCCAGCA 540 $* * * * * * * * * * * * * * * * * * * * * * * * * * * * * * * * * * * * * * * * * * * * * * * * * * * * * * * * * * *$

AL IV 537: GCACCA-GGTTTGCACGCCTCCGTACTTGCACGCATAGTGCAGCGGGTTCATGTCATCCT 595

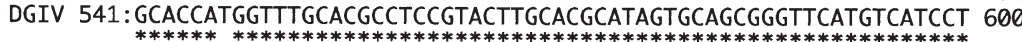

ALIV 596: CATTGGTGGTCATTGTCAGTGCAGGTGCCATTTGCGCGCCATA-TGCGTCAGCAGGTAGC 654 DGIV 601: CATTGGTGGTCATTGTCAGTGCAGGTGCCATTTGCGCGCCATACTGCGTCAGCAGGTAGC 660 : CATTGGTG
$* * * * * * * * * * * * * * * * * * * * * * * * * * * * * * * * * * * * * * * * * * * * * * * * * * * * * * * * * * * * * * * * * *$

ALIV 655: GCACACACCCGTGGTAGGGCTCGGCCAGACACGACACAAGG

DGIV 661: GCACACACCCGTGGTAGGGCTCGGCCAGACACGACACAAGG

701

Fig. 8. DNA sequences of PCR products from ALIV and DGIV. PCR products derived with primers P3-IRB5 and P4-IRB5 from ALIV and DGIV are cloned and sequenced. Dashes indicate nucleotide gaps that are necessary to align these sequences, and the conserved nucleotide between ALIV and DGIV is indicated by an asterisk pairs (bp) (P1-IRB5 and P2-IRB5) (Fig. 7, lanes 2 to 6); $709 \mathrm{bp}$ (P3-IRB5 and P4-IRB5) (Fig. 7, lanes 7 to 11); 445 bp (P1-IRB6 and P2-IRB6) (Fig. 7, lanes 2 to 6); and $797 \mathrm{bp}$ (P3-IRB6 and P4-IRB6) (Fig. 7, lanes 7 to 11). In contrast, there was no PCR product in any iridovirus-free samples from healthy African lampeye and pearl gourami (Fig. 7, lanes 12 and 13 [negative control]).

The nucleotide sequences of the PCR products that were derived with primers P3-IRB5 and P4-IRB5 from ALIV and DGIV were 695 and 701 bp, respectively (Fig. 8). The sequence identity between ALIV and DGIV was $95.3 \%$.

\section{DISCUSSION}

As described in 'Results', the present iridovirus disease of African lampeye and dwarf gourami is characterized by the formation of IBCs, and diseased fish appear to die of necrosis of splenocytes due to the iridovirus infection. This histopathological sign differs from that of a ranavirus infection, or 'epizootic hematopoietic necrosis' (EHN; Langdon et al. 1986, Fijan 1998, Hyatt et al. 2000). EHN virus-infected redfin perch Perca fluviatilis mainly displayed necrosis of hematopoietic cells 
and hepatocytes (Langdon et al. 1986) but no formation of enlarged cells as IBCs. In the previous studies, because the presence of intracytoplasmic inclusion body has not been precisely identified, IBCs have been variously termed amoeba-like organisms (Anderson et al. 1993), hypertrophic cells (Armstrong \& Ferguson 1989), heteromorphic balloon cells (Inouye et al. 1992) and circumscribed bodies (Chua et al. 1994). Although Inouye et al. (1992) reported that iridovirus-infected and enlarged cells of red sea bream contain a mass of DNA within the cytoplasm, they did not consider an inclusion to be induced. The progression of cellular change in the hypertrophic cells of chromide cichlid (Armstrong \& Ferguson 1989) was the same as that of IBCs. These terms are not incorrect but are not adequate for describing how iridoviruses multiply within the infected cells. As does Jung et al. (1997), we use the term 'inclusion body-bearing cells' because the iridovirus-infected cells notably formed an inclusion body within the cytoplasm. Although the formation of an intranuclear inclusion in the circumscribed bodies was stated (Chua et al. 1994), it is now recognized to be an enlarged nucleolus in the present study. In IBCs, the inclusion bodies are composed of virions, rER, sER, ribosomes, mitochondria and the granular matrix that contains DNA. Hedrick et al. (1990) reported that viral DNA was replicated in the cytoplasm of enlarged cells induced by a unique iridovirus of white sturgeon iridovirus. In IBCs, intense replication of viral DNA also appears to occur within the inclusion body following intranuclear replication of viral DNA. Inclusion bodies with this distinctive structure are always induced by infections with ALIV and DGIV, as well as SBIV, RSIV and GSDIV (Jung et al. 1997, Miyazaki unpubl.). These features of inclusion bodies were different from particular inclusions induced by other viruses such as lymphocystis disease virus (Zwillenberg \& Wolf 1968), erythrocytic necrosis virus (Appy et al. 1976, Evelyn \& Taxler 1978, Nicholson \& Reno 1981, Reno et al. 1978), Atlantic cod iridovirus (Smail \& Munro 1989) and striped jack nervous necrosis virus (Jung et al. 1996). Although in catfish infected with catfish iridovirus (Ranavirus) all of the infected cells displayed necrosis (Pozet et al. 1992), catfish iridovirus-infected cultured cells formed an inclusion body but it contained few organelles (Pozet et al. 1992, Hyatt et al. 2000), likely a 'virus assembly site' as found in frog virus (Ranavirus)infected cultured cells (Murti \& Goorha 1983, Goorha et al. 1984).

The present iridovirus disease was found in African lampeye and dwarf gourami just after being imported to Japan from Singapore. In the present study, the results of PCR assays using the 4 primer sets and DNA sequences revealed that ALIV and DGIV are highly identical $(95.3 \%)$ and suggest that they are strains of the same isolate. A similar iridovirus disease was found in dwarf gourami in 1988 (Anderson et al. 1993) and chromide cichlid in 1989 (Armstrong \& Ferguson 1989) that were exported from Singapore. Both dwarf gourami and chromide cichlid have been cultured in Singapore, so they might have the same iridovirus disease. African lampeye is native to Africa, and the fish were imported and bred by Singaporean breeders around 1990, which was after the first finding of iridovirus disease in ornamental fishes described above. African lampeye appear to have been infected with the iridovirus after being imported to Singapore and it is unlikely that they had been infected with the iridovirus in Africa. African lampeye have been cultured not only in Singapore but also on Sumatra Island, where most of the production occurs. Because African lampeye and dwarf gourami are suffering from the same iridovirus, this iridovirus disease appears to have been present in breeding farms in Singapore as well as on Sumatra and in Malaysia.

In the present study, we also performed a multipletargeted PCR diagnosis with 4 iridovirus-specific oligonucleotide primer sets to avoid erroneous results. The 4 sets of primers amplified 4 viral DNA fragments, i.e. 416 bp (P1-IRB5 and P2-IRB5), 709 bp (P3-IRB5 and P4-IRB5), 465 bp (P1-IRB6 and P2IRB6), and 797 bp (P3-IRB6 and P4-IRB6), from 5 iridovirus isolates (ALIV, DGIV, GSDIV, SBIV and RSIV). The PCR assay results indicate that there is genetic homogeneity not only between ALIV and DGIV but also between all 5 iridovirus isolates. The nucleotide sequences of the PCR products that were derived with primers P3-IRB5 and P4-IRB5 from ALIV and DGIV were 695 and $701 \mathrm{bp}$, respectively (Fig. 8). The sequence identity between ALIV and DGIV was $95.3 \%$, indicating that ALIV and DGIV have a single origin. We are attempting to obtain gene sequences of these 5 iridovirus isolates and the results will be shown in a future report. In virus taxonomy (Murphy et al. 1995), the genus Iridovirus is encompassed in the family Iridoviridae and confirmed to infect insects but not vertebrates. Although the taxonomical position of these isolates will be determined after the gene sequences are analyzed, we would like to term this virus 'tropical iridovirus' because most of the host fishes inhabit tropical regions.

Acknowledgements. We express many thanks to Ms. Yaowanit Danayadol of the National Institute of Coastal Aquaculture in Thailand for kindly giving us samples of diseased grouper, and Mr. Toshiyuki Shibata of Japan Pet Drugs Co. Ltd for giving us valuable information about ornamental fish farming in Southeast Asian countries. 


\section{LITERATURE CITED}

Anderson IG, Prior HC, Rodwell BJ, Harris GO (1993) Iridovirus-like virions in imported dwarf gourami (Colisa lalia) with systemic amoebiasis. Aust Vet J 70:66-67

Appy RG, Burt MDB, Morris TJ (1976) Viral nature of piscine erythrocytic necrosis in the blood of Atlantic cod (Gadus morhua). J Fish Res Board Can 33:1380-1385

Armstrong RD, Ferguson HW (1989) Systemic viral disease of the chromide cichlid Etroplus maculatus. Dis Aquat Org $7: 155-157$

Chua FHC, Ng ML, Ng KL, Loo JJ, Wee JY (1994) Investigation of outbreaks of a novel disease, 'sleepy grouper disease', affecting the brown-spotted grouper, Epinephelus tauvina Forskal. J Fish Dis 17:417-427

Danayadol Y, Direkbusarakom S, Boonyaratpalin S, Miyazaki T, Miyata M (1996) An outbreak of iridovirus-like infection in brown-spotted grouper (Epinephelus malabaricus) cultured in Thailand. AAHRI Newsl 5:6

Evelyn TPT, Taxler GS (1978) Viral erythrocytic necrosis: natural occurrence in Pacific salmon and experimental transmission. J Fish Res Board Can 35:903-907

Fijan N (1998) Spring viremia of carp and other viral diseases and agents of warm-water fish. In: Woo PTK, Bruno DW (ed) Fish diseases and disorders, Vol 3. CABI Publishing, Oxon, p 117-244

Goorha R, Granoff A, Wills DB, Murti KG (1984) The role of DNA methylation in virus replication: inhibition of frog virus-3 replication by 5-azacytidine. Virology 138:94-102

He JG, Wang SP, Zeng K, Huang ZJ, Chan SM (2000) Systemic disease caused by an iridovirus-like agent in cultured mandarinfish, Siniperca chuatsi (Basilewsky), in China. J Fish Dis 23:219-222

Hedrick RP, Groff MJ, McDowell T, Wingfield WH (1990) An iridovirus infection of the integument of the white sturgeon Acipenser transmontanus. Dis Aquat Org 8: 29-44

Hyatt AD, Gould AR, Zapanovic Z, Cunningham AA, Hengstberger S, Whittington RJ, Kattenbelt J, Coupar BEH (2000) Comparative studies of piscine and amphibian iridoviruses. Arch Virol 145:301-331

Inouye K, Yamano K, Maeno Y, Nakajima K, Matsuoka M, Wada Y, Sorimahi M (1992) Iridovirus infection of cultured red sea bream, Pagrus major. Fish Pathol 27:19-27 (in Japanese with English summary)

\author{
Editorial responsibility: Jo-Ann Leong, \\ Corvallis, Oregon, USA
}

Jung SJ, Oh MJ (2000) Iridovirus-like infection associated with high mortalities of striped beakperch, Oplegnathus fasciatus (Temminck et Schlegel), in southern coastal areas of the Korean peninsula. J Fish Dis 23:223-226

Jung S, Miyazaki T, Miyata M, Oish T (1996) Histopathological studies on viral nervous necrosis in a new host, Japanese sea bass Lateolabrax japonicus. Bull Fac Bioresour Mie Univ 16:9-16 (in Japanese with English abstract)

Jung S, Miyazaki T, Miyata M, Danayadol Y, Tanaka S (1997) Pathogenicity of Iridovirus from Japan and Thailand for the red sea bream Pagrus major. Fish Sci 63:735-740

Langdon JS, Humphrey JD, Williams LM, Hyatt AD, Westbury HA (1986) Fish virus isolation from Australian fish: iridovirus-like pathogen from redfin perch, Perca fluviatilis. J Fish Dis 9:263-268

Miyata M, Matsuno K, Jung SJ, Danayadol Y, Miyazaki T (1997) Genetic similarity of iridoviruses in Japan and Thailand. J Fish Dis 20:127-134

Murphy FA, Fauquet CNM, Bishop DHL, Ghabrial SA, Javris AW, Martelli GP, Mayo MA, Summers MD (1995) Virus taxonomy. Classification and nomenclature of viruses. Springer, New York

Murti KG, Goorha R (1983) Interaction of frog virus-3 with the cytoskeleton. I. Altered organization of microtubules, intermediate filaments and microfilaments. J Cell Biol 96: 1248-1257

Nicholson BL, Reno PW (1981) Viral erythrocytic necrosis (VEN) in marine fishes. Fish Pathol 15:129-133

Pozet F, Morand M, Moussa A, Torhy C, de Kinkelin P (1992) Isolation and preliminary characterization of a pathogenic icosahedral deoxiribo-virus from the catfish Ictalurus melas. Dis Aquat Org 14:35-42

Reno PW, Philippon-Fried M, Nicholson BL (1978) Ultrastructural studies of piscine erythrocytic necrosis (PEN) in Atlantic herring (Clupea harengus harengus). J Fish Res Board Can 35:148-154

Sambrook J, Fritsch EF, Maniatis T (1989) Molecular cloning: a laboratory manual, book 2. Isolation of DNA from mammalian cells, 2nd edn. Cold Spring Harbor Laboratory Press, Cold Spring Harbor, p 16-22

Smail DM, Munro ALS (1989) The virology of teleost. In: Roberts RJ (ed) Fish pathology. Bailliere Tindall, London, p 173-241

Zwillenberg LO, Wolf K (1968) Ultrastructure of lymphocystis virus. J Virol 2:393-399

Submitted: April 30, 2001; Accepted: September 12, 2001 Proofs received from author(s): March 22, 2002 